\title{
SAINT MARTIAL OF LIMOGES AND THE MAKING OF A SAINT
}

\author{
Claude Andrault-Schmitt
}

\begin{abstract}
The purpose of this paper is to comment on the case of St Martial in Limoges, an understanding of which should be refreshed by discussion arising from the recent archaeological campaigns. In 2019, it appears more clearly than ever that the church dedicated to the Saviour was only one of the buildings in a complex that demonstrated that this really was the burial site of the saint. While the Carolingian period seems decisive, various layouts were created between the 3rd and the 18th century, so forming a continuous Christian memory. A principle of accumulation derived from legendary cults affected the funerary furniture and consequently the building sequence. This paper discusses the lost main church as both a building of the supposed 'Pilgrimage roads' as well as in its regional Romanesque context.
\end{abstract}

\section{THE LOST ABBEY CHURCH}

The design of the Romanesque church of St Martial consisted of an ambulatory with five radiating chapels; two aisled transept arms made short by the presence of small churches to the north, with an apse on each transept; numerous nave bays, with upper galleries, and a western tower that was heightened with picturesque gables. ${ }^{1}$ On its northern side, it was completed by a beautiful Gothic cloister and its ranges.

Despite being entirely demolished, the building can be analysed thanks to numerous and remarkable 18th century drawings: first, the 'plan Legros' of 1784 (Figure 9.1), which is very useful for the structure and the liturgical functions, but misleading for the axis and dimensions; second, an unexpected cross-section which also represents the ornament of a principal shrine, drawn in 1726 (Figure 9.2). ${ }^{2}$ We have also a view of the apse. But we must place in the first rank the plan produced in 1765 by Trésaguet, a town-planner. ${ }^{3}$ These drawings, especially the dimensions included in its minutes, were made in the according to modern requirements with an attitude informed by the Enlightenment (Figure 9.3). Their dimensions, their layout, and their axes are very reliable, as was demonstrated by the recent excavations of $2012-17 .{ }^{4}$ The scale, however, is that of the entire town, and therefore the brief 1960s excavations and plans focused rather on Canon Legros' work. ${ }^{5}$

I would only retain a few dates of those cited concerning the Romanesque building sequence. Some facts do not deserve to be repeated here, such as the fires in 1043, $1053,1060,1122-23,1167$ : these sorts of events, as many know, are generally overestimated in their importance. In 1018-30, a cult for Martiali primo Galliarum patroni ${ }^{6}$ or Martial as an Apostle, was promoted through all possible media. According to the musicologist James Grier, the most important event of this period was 'an outrageous ecclesiastical fraud'. ' On 3 August 1029, the monks of St Martial inaugurated in the cathedral St Etienne a new liturgy proclaiming their patron a 1st-century saint, intimate of Christ, and also the first of the evangelising bishops. ${ }^{8}$ The author of the texts was Ademar de Chabannes. ${ }^{9}$ This historian, musician, draughtsman, well known as a forger, was a traveller-monk who lived more or less under the obedience of the abbots Geoffrey ( $\dagger$ 1019), Hugo $(† 1025$ ?) and Odolric († 1040). Alain Dierkens considers that Ademar had inherited his ideas from his uncle 'Roger the cantor' and took up the tradition of the scriptorium. The polemical liturgical compositions correspond to the writing of the Vita prolixior Martialis secunda (also by Ademar) and to a new mise-en-scène of the tomb in the abbey. This was placed beyond the western end of the little church of St Pierre (to the north of the great church), the dedication of which reminds us that Peter was reputed to be Martial's mentor and cousin. Consequently, we must be interested in this little church and its western Sepulchre, the remains of which can be seen today inside an archaeological crypt, as much as in the beginnings of the Romanesque abbey church. Most likely the connection between the burial place and the Romanesque ambulatory were planned at the same time, because Ademar de Chabannes also reported that between 1017 and 1021 the abbot ordered a sumptuous new building: a novo basilicam Salvatoris magnifico opere instauravit. ${ }^{10}$ The work began 


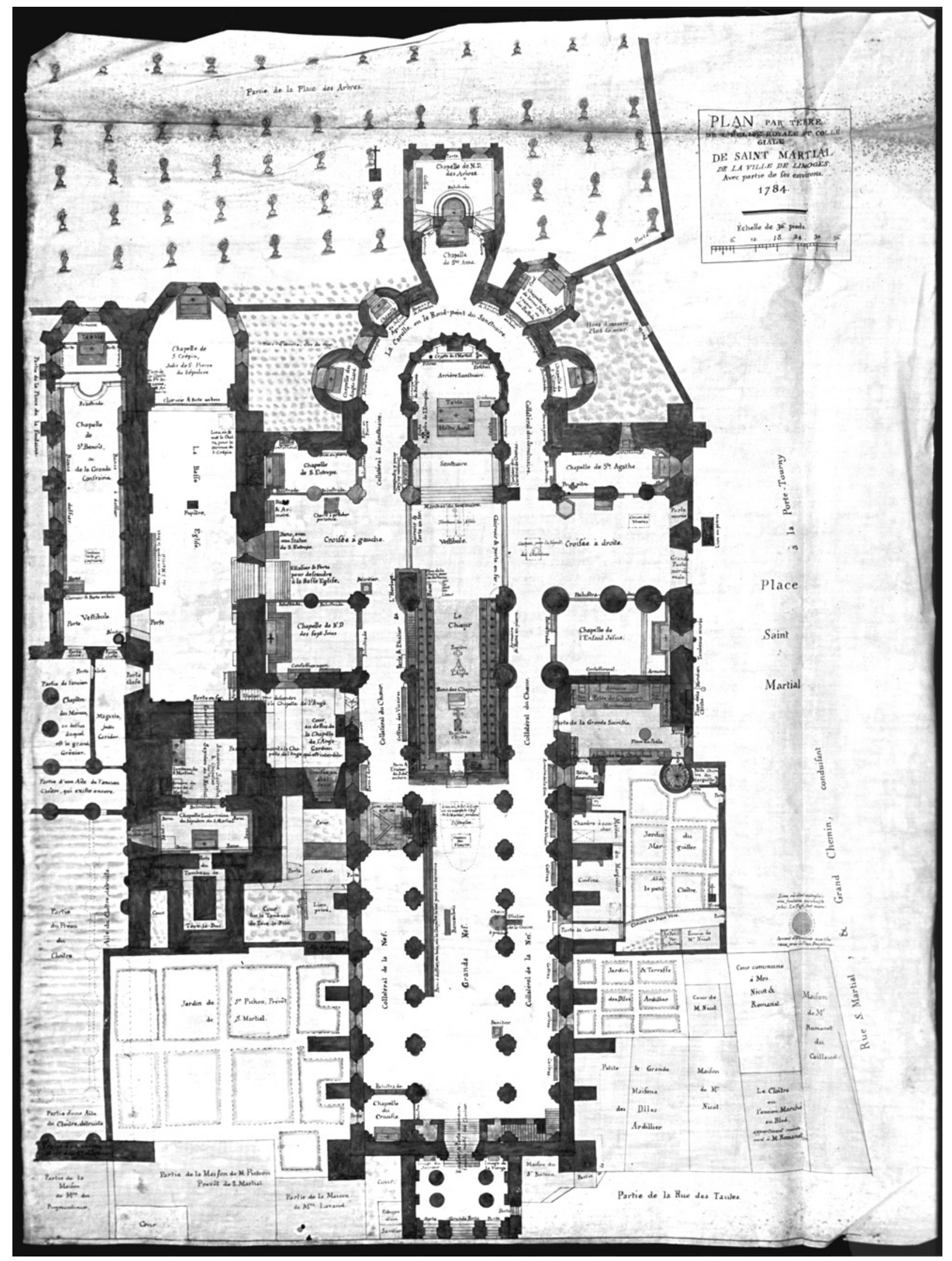

FigURe 9.1

Limoges: St Martial, plan by Legros (1784) 


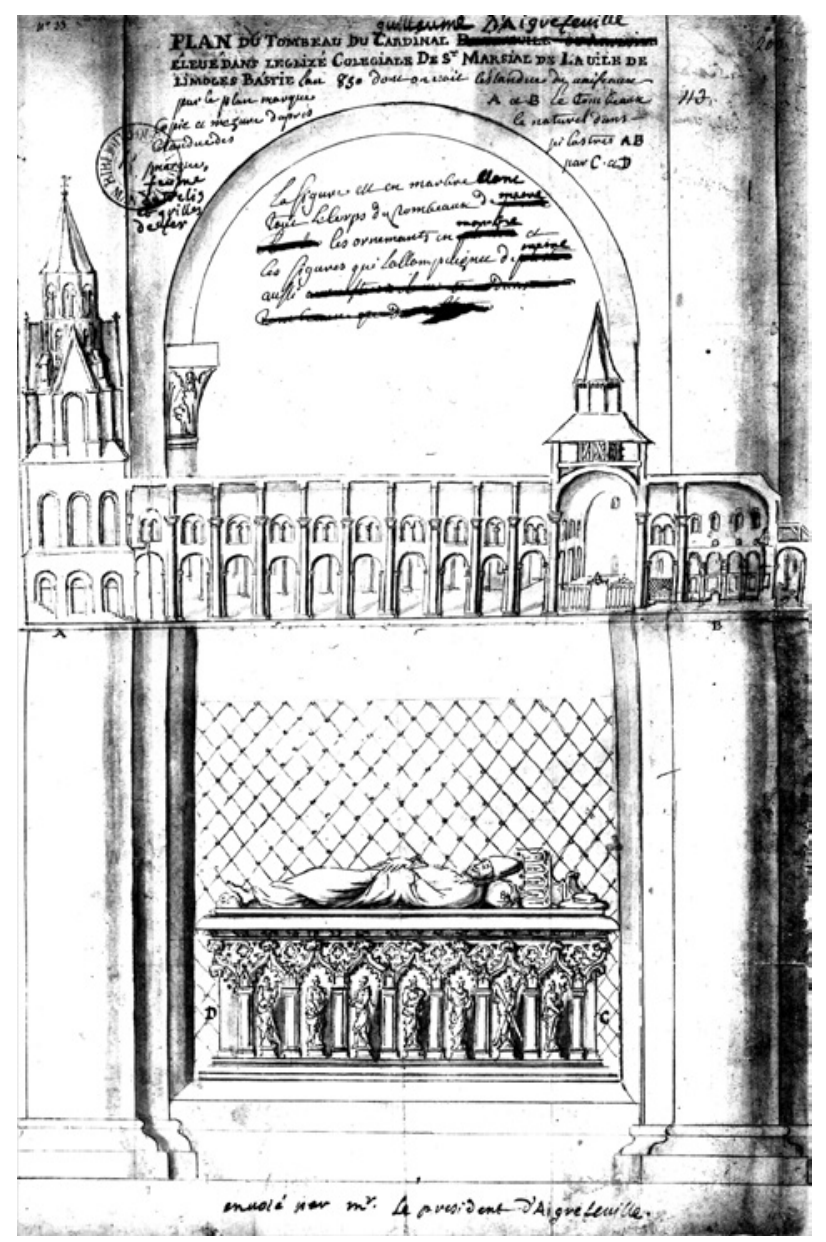

FigURE 9.2

Limoges: St Martial, Montfaucon drawing (BnF, Estampes, Va 87)

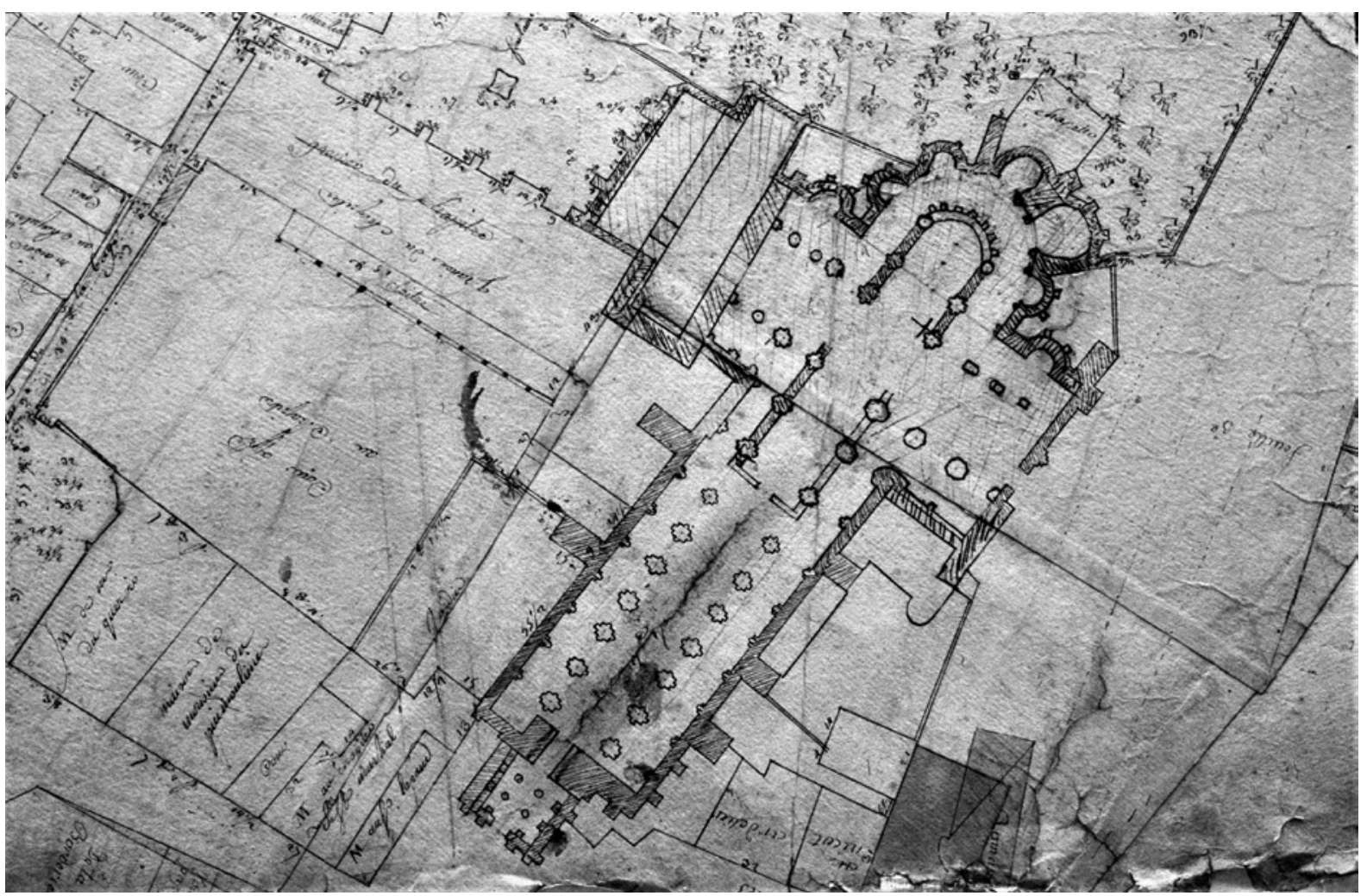

FIGURE 9.3

Limoges: St Martial, Tressaguet plan; arch. dép., C 65 (Arch. dép.) 
just after a journey by the relics of St Martial to celebrate the discovery of St John's head at St Jean d'Angely ${ }^{11}$ and after the death of more than 50 pilgrims at Limoges inside a church supposedly too narrow to accommodate them.

Whenever the fabric was begun, it is absolutely certain that a dedicatio took place on 19 November 1028: fecit dedicare caput istius ecclesie cum magno honore. ${ }^{12}$ The ceremony was celebrated by eleven bishops: from Bordeaux, Limoges, Poitiers, Angoulême, Périgueux, Gérone, Cahors, Albi, Rodez, Carcassonne, and Saintes. The saint was then 'elevated' but he returned to his 'proper' sepulchre after eight days. ${ }^{13}$ It is interesting to note that the event seemed significant enough to enter as a day of celebration in a later obituary list before being suppressed by Cluny. ${ }^{14}$ It was roughly contemporary to the writing of a new and longer Vita, to the introduction of the new liturgy, to the gathering of synods to proclaim Martial's apostolic status, ${ }^{15}$ and to the foundation of an altar of St Martial in St Peter's in Rome by John XIX. ${ }^{16}$ Nevertheless, we must conclude that Ademar's tactics failed partly because he was forced to return to his proper abbey in Angoulême and then to leave for Jerusalem, where he died. Most of his letters and sermons 'were left in his habit' and not widely published. ${ }^{17}$ Fortunately, the architectural consequences were durable.

Half a century later, in 1063, when Cluny violently annexed St Martial, ${ }^{18}$ a marble altar bought at Narbonne by Odolric was supposedly left outside, waiting for its proper place. The first Cluniac abbot, the Limousin Ademar de Laurière, ${ }^{19}$ completed the building between altare sancti crucis usque ad portam occidentalis, including the vault paintings. ${ }^{20}$ In 1095 , the consecration by Pope Urban and eight bishops obviously was for a church brought to completion.

The investigations conducted by 'Eveha' under the supervision of the Service Régional d'Archéologie have recently managed to unearth some parts of this fabric in spite of deep cutting works for a modern theatre. ${ }^{21}$ But the main archaeological surprises open up larger subjects than the architecture of the abbey church itself.

\section{THE SINGULARITY: A MISE-EN-SCÈNE OF CHRISTIAN ANTIQUITY WITH SEVERAL MAUSOLEA}

As one of the two medieval towns of Limoges (the other was La Cité around the cathedral), Le Château was surrounded by its own walls (Figure 9.4), which included a Carolingian palace in the higher area and a religious community in the lower one. In this lower part, at the edge of the Place de la République, archaeologists have recently cleaned the archaeological crypt arranged in the 1960s, studied the oldest and unknown remains of the little northern churches, found some other early Christian graves, and offered a new historical survey. They have also begun to propose an extensive interpretation of the urban fabric, up to then poorly understood. Unfortunately, the doors, stairs, and all connections between the small northern churches and the huge pilgrimage church were not found. But it is certain that these older buildings, which were modernised from century to century, explain some of the features of the Romanesque church: first of all the size of the crossing and the shortness of the transept.

\section{South: a mausoleum to diversify the relic cult}

At least three mausolea seemed to have crystallised the relic cult. ${ }^{22}$ This part of Limoges was mostly a necropolis. The recent Carbon 14 dating for one of the tombs to 253 $\mathrm{AD}$ is earlier than the usual estimate. However, contrary to what has previously been thought, the place was not only a funerary area during the first millennium; it was also more or less densely urbanised.

Concerning the south section of the neighbourhood, more than 200 sarcophagi were found in 2012, which must be added to the 150 unearthed in 1892 . Funerary practices are testified until the beginning of the Romanesque period, in spite of an interruption lasting the whole of the 9th century. Fortuitously, a little building has been discovered under a shop, $70 \mathrm{~m}$ from the abbey church. ${ }^{23}$ It corresponds to a chapel recognised in old town maps as Sainte-Marie-de-la-Courtine, which belonged to the abbey and was razed to the ground in 1742 . In the 12 th century, this church was supposed to shelter the grave of the architect of the tomb of St Martial, Amasius, but the cult of the Virgin later prevailed. ${ }^{24}$ It initially had a centralised square design and was built as a funerary spot. Then (c. 400-550) it was Christianised, housing a favoured grave, painted, with stone vaults, and two or three apses (north, south, west). It was extended to the east and converted into a church $c .600$ (the same period as the Roman Pantheon was converted into Sancta Maria ad Martyres); at that time the south and north apses were removed.

\section{North: St Pierre as the first basilica joined to the apostolic mausoleum}

Against the north end of the Romanesque transept, which consequently received an oblique north wall, we can still recognise St Pierre du Sepulchre also called the BasseEglise (Low Church). This was actually the basilica described by Gregory of Tours. The church was first built with a square chevet and was initially separated from the mausoleum by an atrium (perhaps as a recollection of Jerusalem). Beyond the atrium, the western part of the Low Church was shaped like a double or triple cave, and was from an early date (c. 680) named domuncula, 'the little house' (Figure 9.1). ${ }^{25}$ Legendary sources said that it was required to house the grave paid for by Valeria and prepared for herself and the famous bishop she had assisted. St Valeria was a rich friend of Martial and a decapitated martyr, invented in the Carolingian Vita antiquior of Martial (c. 850), whose 'ring' would help to make Richard 


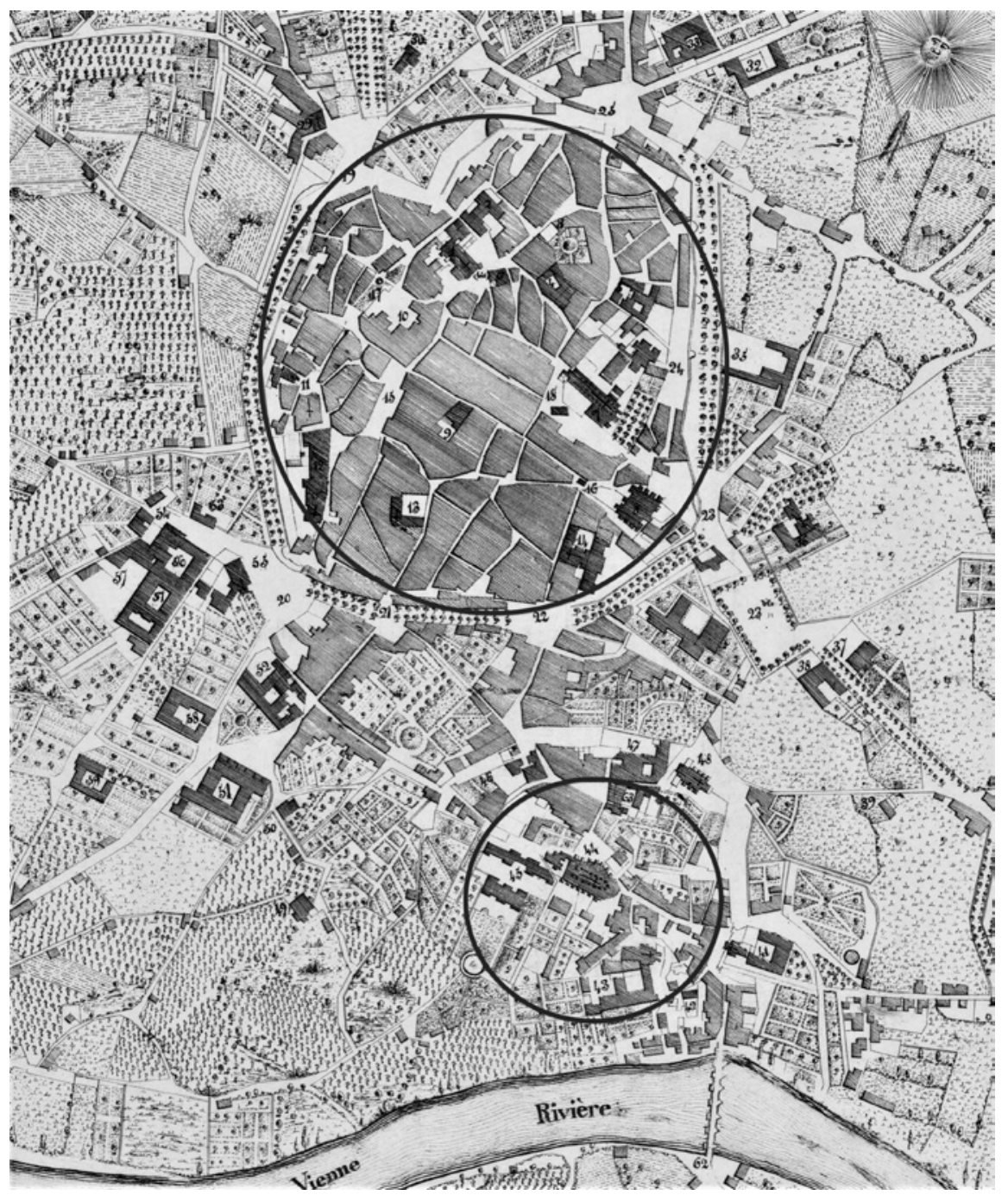

FIGURE 9.4

Limoges: Plan Tripon, 1837, after Trésaguet: The Saviour is at 18; Sainte-Marie-de-laCourtine is at 16; and Limoges Cathedral is at 44 (BnF, Gallica)

the Lion-Heart a duke of Aquitaine. ${ }^{26}$ The funerary spot assigned to Valeria (and consequently to Martial) was probably located in this same place 150 years at least after the historical death of Martial; the cult of Martial existed in 572 among a community of priests. ${ }^{27}$ The whole church including the atrium and the mausoleum was possibly built by Bishop Rurice I (c. 480-after 506), but the main sarcophagi had been moved earlier. ${ }^{28}$

In this section of Le Château, the funerary practices stopped as early as the 8th century. In c. 974, the Sepulchre was supposedly destroyed by a fire. ${ }^{29}$ At the beginning of the 11th century, possibly in accordance with the acts and texts by Ademar, the site where Martial was evoked was adorned with a hanging crown made of gems and gold (which has disappeared) and with an authentication carved recto-verso on a pink marble slab (which has been rediscovered) (Figure 9.5). Nearby an unexpected mosaic (two birds and a vase) was found in the 1960s (Figure 9.6).$^{30}$ In 1220, 195 painted golden stars were ordered for the blue vault of the Sepulchre by the chronicler, cantor and armarius Bernard Itier. ${ }^{31}$ It seems that the aedicule had for a long time the title cripta aurea, either because it was the funeral spot of several saints with rich liturgical furniture or because it was used as a treasury - which reminds us of a sermon by Ademar, who justified the use of jewels by saying they signified spiritual wisdom, eloquence, and virtue..$^{32}$ In the 17 th and 18 th centuries, this section was still called 'the Sepulchre cave' or 'the sacred Sepulchre of St Martial which is closed by an iron door and is vaulted'. As an 18th -century account has it: 'At the end of the crossing [of the Saviour church] on the left is a staircase to go down to two big chapels parallel to the great church. In the first one we will find tunnels where one finds the tomb of the famous Limousin Apostle'. ${ }^{33}$ The ceremonial recorded just before the French Revolution for the Ostensions included the place where the pilgrims used to kiss the relics of St Martial's arm, which was always kept inside a cupboard in the domuncula. ${ }^{34}$ The durability of the cult practices is therefore remarkable. From 1028 to the razing of the churches, a complex route enabled pilgrims to go down to some surviving halfburied buildings which the monks left visible as a demonstration of the authenticity of the saint's grave.

St Pierre was filled with sarcophagi made from granite which corresponded to the various burials ad sanctos. One of them was said to be the sarcophagus of Valeria (near and opposite to the supposed Martial tomb), two others of the bishop's two companions. The bigger one (now in the 

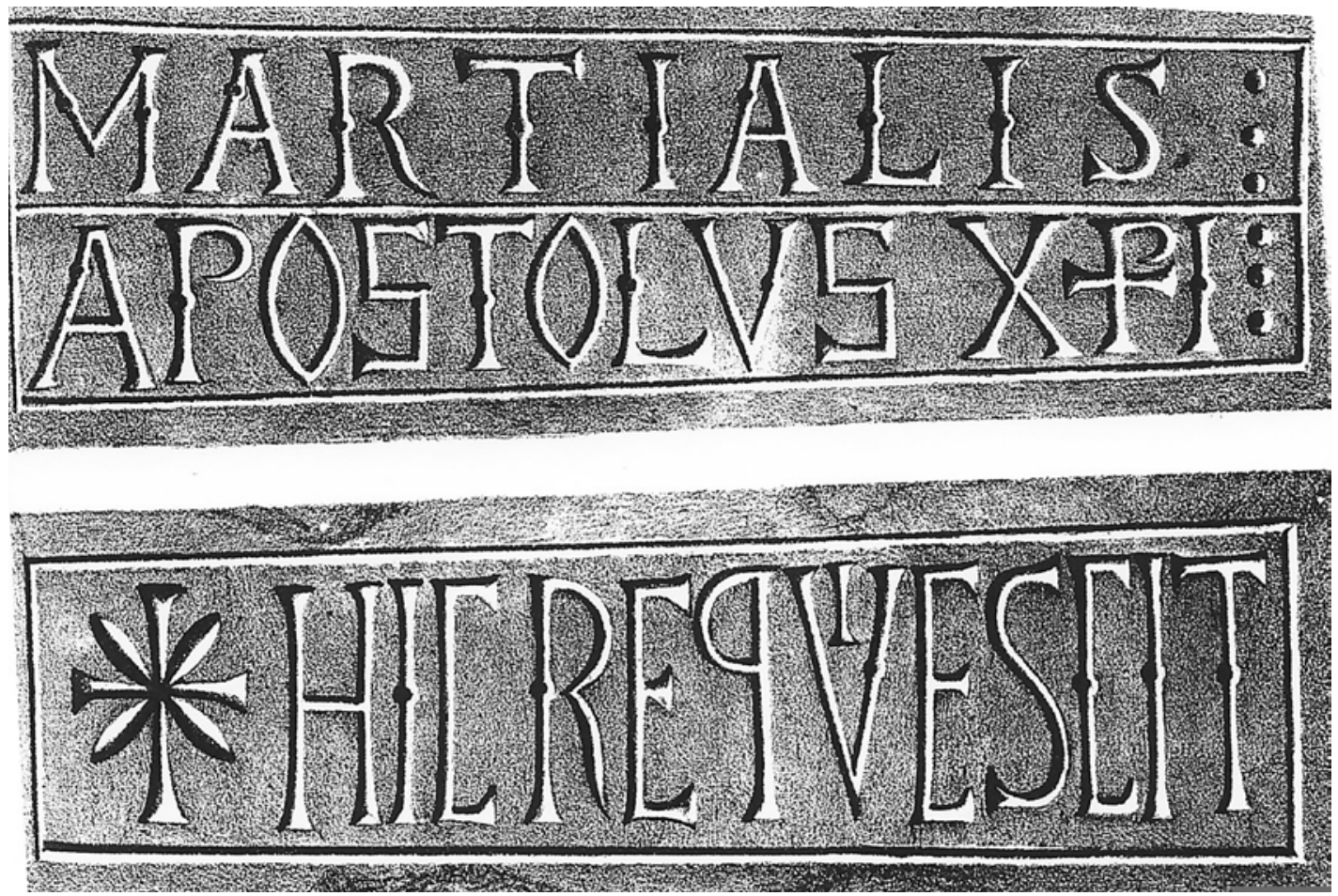

FIGURE 9.5

Limoges: Museum, authentication slab (CIFM, Poitiers)

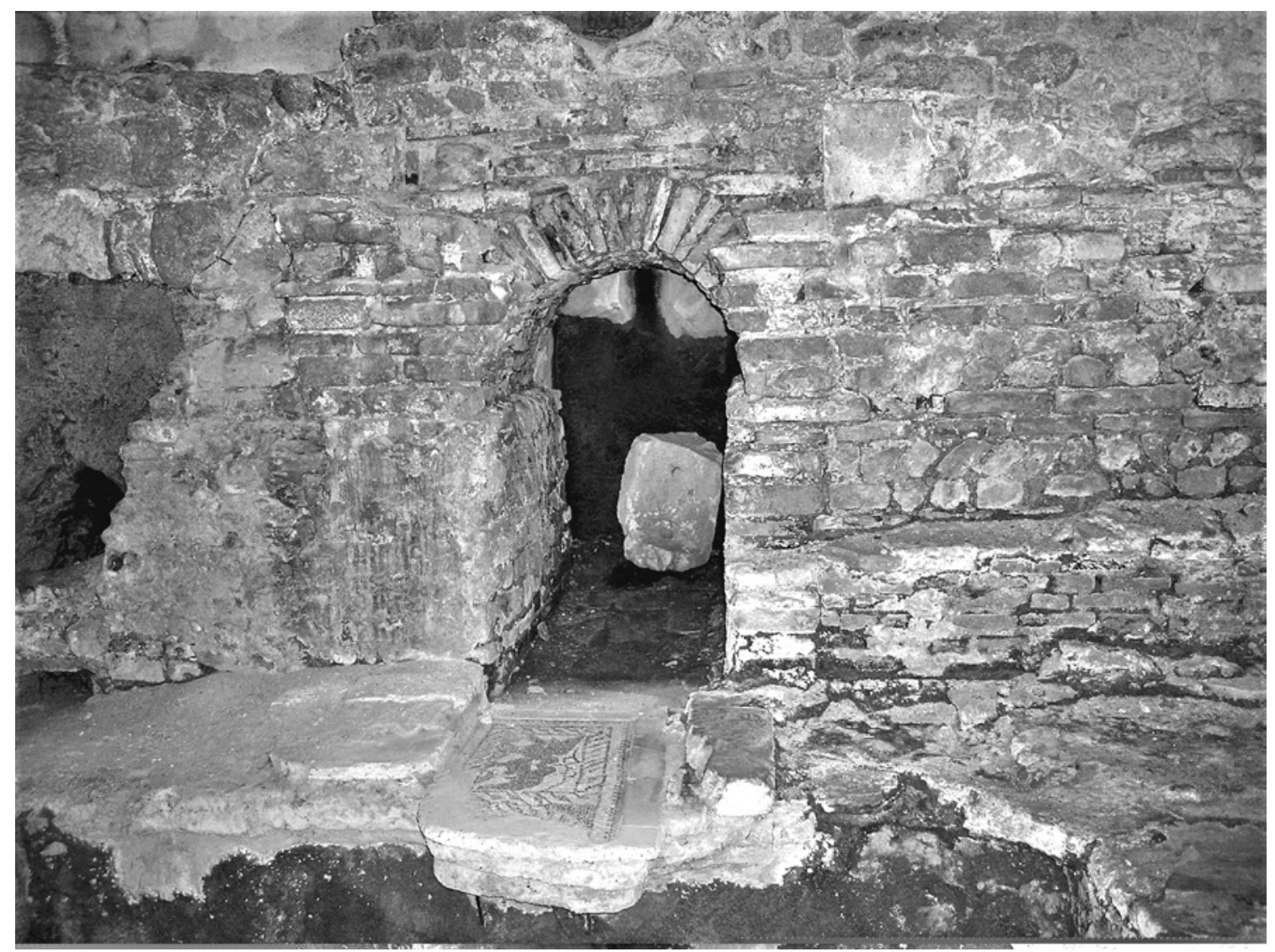

FIGURE 9.6

Limoges: St Pierre du Sépulcre, mausoleum (Claude Andrault-Schmitt) 
museum) was in the west niche of the west cave; it was that of the legendary Duke of Aquitaine, the pagan fiancé of Valeria. ${ }^{35}$ The numerous early medieval sarcophagi that were clustered there increased the drama of the site. The most ancient are monolithic and very big (almost 3 metres long); intended, perhaps, to impress the pilgrims (as what is bigger is older?). Interestingly enough, the earliest sources report that it was very difficult to distinguish the Apostle's grave from those of his two fellow priests in the narrow space, and that nobody could lean over far enough to light a candle on the proper stone lid. ${ }^{36}$

Archaeologists now consider that this mausoleum has never been studied in a proper fashion, and, moreover, that dating is impossible because of the numerous reorganisations, century after century. But they have discovered another amazing funerary space at the opposite, east, end of St Pierre. A sarcophagus had been integrated in the masonry of the apse that replaced the earlier square chevet. Then it was encased in a sarcophagus made of four limestone blocks cramped together, which itself contained pieces of a lead coffin and an empty sarcophagus-shaped reliquary: a cenotaph made like a Russian doll! ${ }^{37}$ The axial sarcophagus was flanked by two later sarcophagi. The southern one is well-dated to between 602 and 674. Was this the grave of saint Loup ( $†$ 634), a bishop still venerated every seven years during the famous Ostensions in Limoges? There is no doubt that an accumulation principle was at work here. The cults of local and legendary saints who were neither Martial nor Valeria reinforced the sanctity of the famous pair and promoted urban patriotism.

\section{Centre: a surprising mausoleum at the heart of the Romanesque Church}

To further complicate the questions, the latest clearance unearthed a fascinating building under the basilica of the Saviour itself. It is important before proceeding to note that unlike the pars orientalis, the crossing and the nave of the main church are very difficult to grasp, because of the deep cutting works for the theatre and because of the many earlier walls.

Lying directly beneath the crossing was a half-buried building with a western apse, each cut-off corner featuring a cruciform recess (Figure 9.7). At its exact central point is a well, far too deep to be investigated, that might give a key to the interpretation of the Romanesque geometry. Its dating is between the 7th century and that of the Romanesque foundations. Unfortunately, its eastern parts are lost, so we can understand neither its connection to the presbytery nor the different ground levels: were the levels of the Romanesque crossing and main apse raised by this strange crypt?

Other questions arise. Did the cruciform recesses symbolise the cult of the true Cross, which was favoured by the Carolingian kings? Was the central mausoleum contemporary to the donations by Louis the Pious and Charles the Bald? It is necessary here to recall the importance of the Carolingian princes for Limoges. These princes conferred the title of 'Royal Basilica' on the church. Louis the Pious,

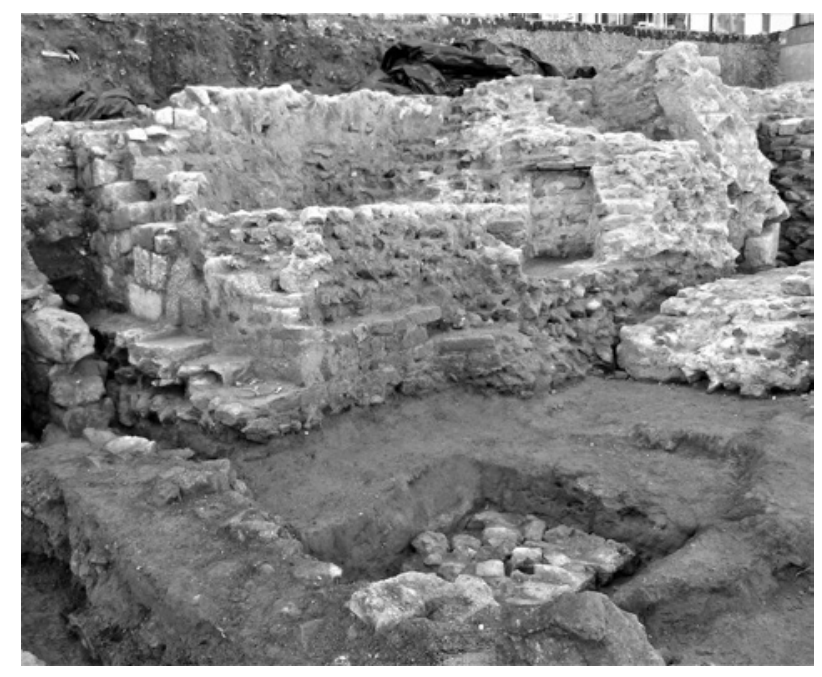

FIGURE 9.7

Limoges: Place de la République, excavations, the mausoleum under the crossing of the Romanesque church (Claude Andrault-Schmitt)

king of Aquitaine as a child (781) before becoming emperor, was supposedly present at the dedication and the transfer of Martial's body in the $830 \mathrm{~s}$; he had previously signed a diploma in the 'monastery of St Martial', as early as $828 .^{38}$ As for Charles the Bald, he crowned his son Charles the Child in the basilica called St Sophia or St Saviour in 855 as the king of Aquitaine. The Carolingian guardianship was still powerful under Louis IV d'Outremer and until the year 994, when the new patron, the duke of Aquitaine, asked Abbot Uzerche and some of his monks to rule the abbey.

Should we identify the excavated central spot with a 'crypt' behind the high altar in which the body was placed during that period according to Ademar? Was it the 'new sepulchrum' he alluded to several times? Ademar said that this sepulchrum was planned just before the removal of the relics to Solignac (Haute-Vienne) to escape the Normans (845-51). He added that Martial did not want to stay in this new place, an opinion he expressed through imposing a cold winter and torrential rains. The loquacious monk tells us that in Francia the weather became fine again, but that in Aquitania the rain did not stop until Martial was returned to his former place. ${ }^{39}$ Ademar displayed in his first written works the stubborn determination to justify the principles he acted on during his whole life. He later wrote: 'we kept the body of our great patron hidden elsewhere than desired by God's will'. ${ }^{40}$

\section{THE ARCHETYPE: A 'PILGRIMAGE CHURCH'?}

\section{The archaeological discoveries: the Carolingian precedent and the ambulatory foundations}

The 'royal' Carolingian basilica was set out under the Romanesque church between Ste Marie and St Pierre, 
nearer St Pierre of course. Some substructures may correspond more or less to the 830 s building reported in the textual sources. However, it is difficult to evaluate accurately not only the masonry remains, but also the dating of the main events: it is impossible to distinguish between the first appearance of a basilica dedicated (or not) to the Saviour (830-2) and the adoption of the Benedictine rule in 848 . It is certain that the prejudice against simple priests (identified as canons) fits with the 'reform' promoted by Louis the Pious and Benedict of Aniane, but the application of the label Benedictine by medieval historians seems a little anachronistic and biased.

The first relevant structure found by the archaeological team under the church of the Saviour was converted into a church (if it was not already a church) with a half-buried polygonal central mausoleum and a proper chevet, probably during the 9th century. This credibly Carolingian church seems to have been surrounded by new houses and streets. The ground between it and St Pierre was left largely open, ${ }^{41}$ with several tombs and another well, later encased in the Romanesque church. A few years later the nave foundations were reinforced, two aisles were built, and the access to the central mausoleum was altered. Still later, one of the Carolingian walls was strengthened so as to form a grid to support the eastern aisle of a north transept (Figure 9.8). All these sequences are very intricate and difficult to apprehend, apart from a sequence in the 10th century with pits to melt metal and glass against the mausoleum, which gives some chronological insights.

Concerning the eastern arm of the Romanesque church, partly unearthed, as I have said the Trésaguet drawings are accurate. The geometry of the ambulatory and its radial chapels was perfect, as if drawn with a compass. The church caput was freely planned on a completely razed section of land, and suggests a dating in the early 11th century - with the same design as at Orléans ( St Aignan) or Tours (St Martin).

The surprise came from the foundations which stand to a considerable height, more than 4 metres under the supposed medieval ground level. The masons dug down as far as the bedrock, which was very deep because of the natural slope. This was not in order to plan a crypt, because afterwards they filled up the excavation with the material removed; there are no windows but only putlog holes (Figures 9.9 and 9.10). Given these observations,

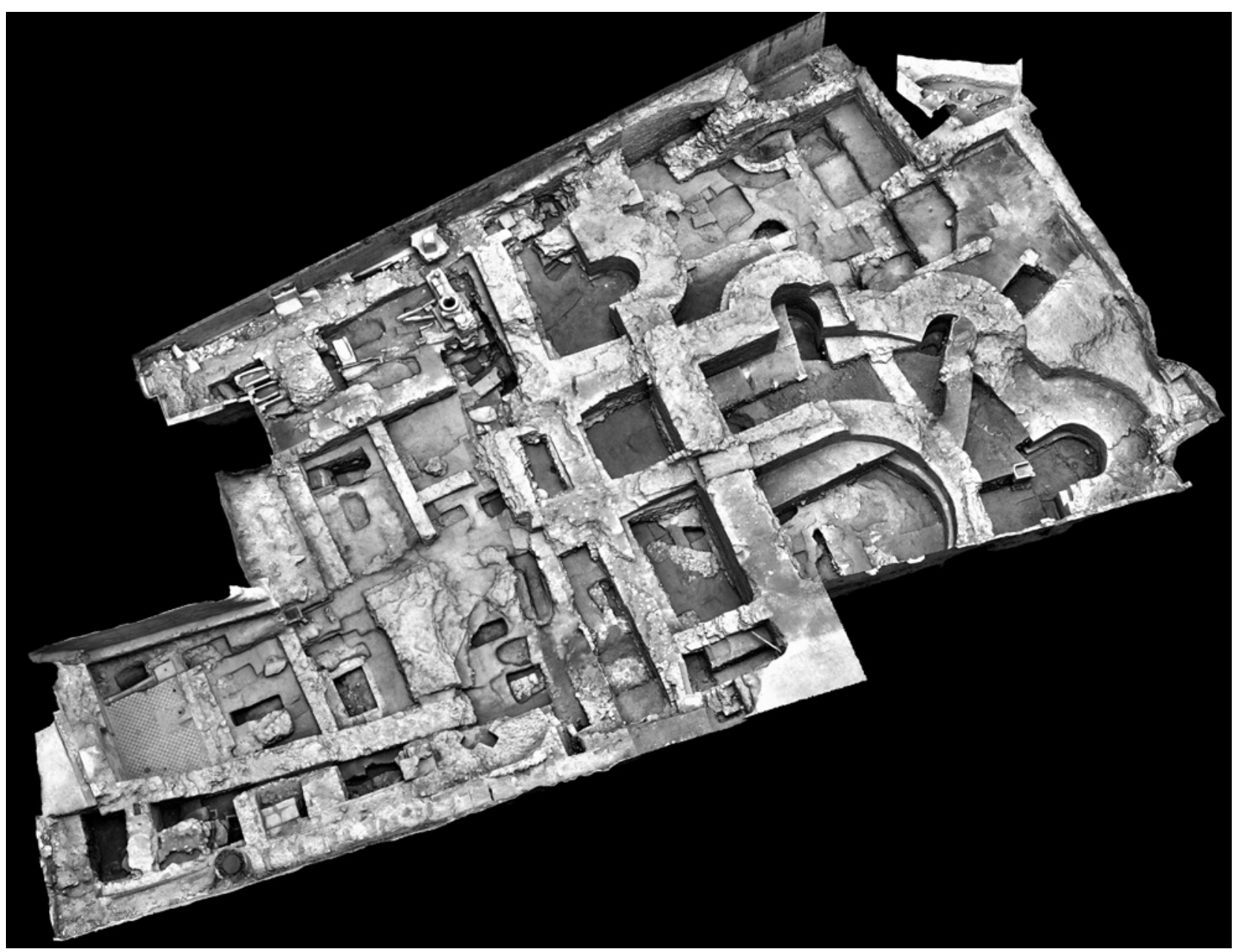

FigURE 9.8

Limoges: Place de la République, excavations, 3D and photogrammetry, by Nicolas Saulière (Eveha) 


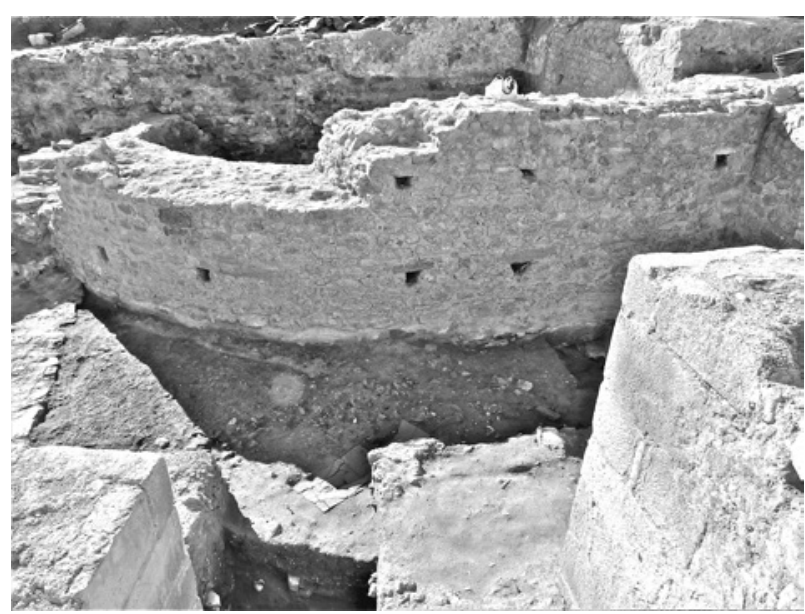

FigURE 9.9

Limoges: Place de la République, excavations, St Saviour, ambulatory (Claude Andrault-Schmitt)

the high quality of the masonry is quite amazing. There is coursed rubble with ashlar dressing, Roman spolia, reused coloured stones and stained concrete, perfect covering joints and 'buttered' joints to protect the walls from dampness: all sophistications which are unexpected when found under the ground. In spite of the lack of definitive evidence, the features suggest an undertaking of the period of Ademar, and represent a building of unexpected ambition.

It is likely that the new chevet and its ambulatory extended far beyond the Carolingian nave, the half-buried mausoleum and a related broad transept built largely before the 1020s to join the abbey church to St Pierre. Its later extension by a new nave suited to its dimensions remains unclear. The elevation opens up the same questions as those for Conques: the galleries and vaults probably belong to a later phase (after the 1043 fire?). These points will never be clarified. Let us now, then, comment on the entire church as finished at the end of the 11th century, as it was seen by the Galician bishop Diego Gelmirez during his trip to Limoges.

\section{The Romanesque church as part of a series?}

Without any doubt, the scheme belongs to a series of buildings improperly called 'pilgrimage churches' (Tours, Limoges, Conques, Toulouse, Compostella). The formula assigns six structural features, all of which are present in those five churches and only those five: an ambulatory with five radiating chapels; an uninterrupted set of aisles; upper galleries, also uninterrupted except inside the apse; no clerestory; a barrel vault for the main nave; a roundheaded design for all the arches and vaults.

I don't want to comment on this much-discussed concept, which is now recognized as a specious and outdated construction, and I will confine myself to mention two points. Firstly, the building series and the famous Liber sancti Jacobi must be disconnected, because this part of

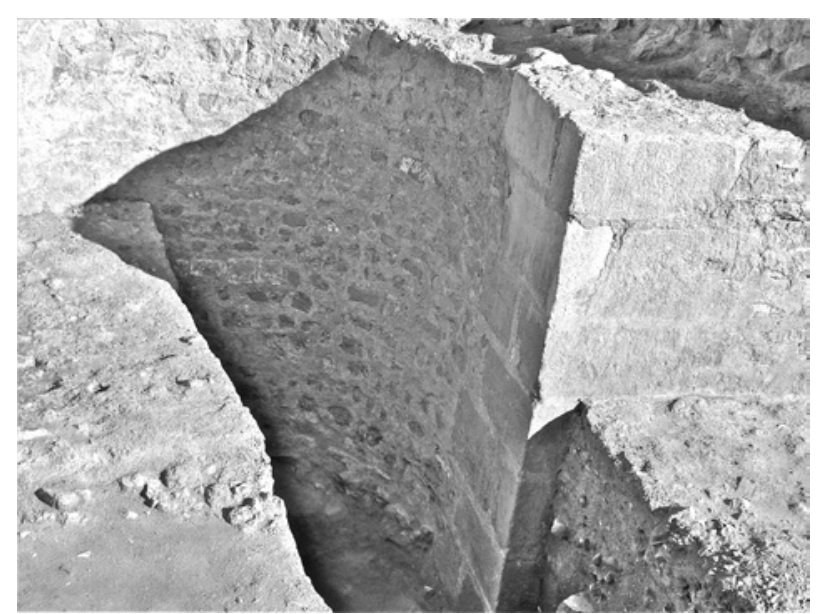

FIGURE 9.10

Limoges: Place de la République, excavations, St Saviour, a radiating chapel (Claude Andrault-Schmitt)

the codex also praised St Eutrope at Saintes, St Hilaire at Poitiers, and St Gilles-du-Gard, which are very differently shaped, and above all because the author avoided a stage at St Martial and preferred St Leonard-de-Noblat (maybe he hated Cluniac monks!). Secondly, an intentional type would imply that the builders were obsessed by a Compostellan model and wished to pre-figure it at earlier points on the route to Santiago. But the truth is that the five churches were more or less contemporary, ${ }^{42}$ and that the Spanish example was not the first, but the last to use the ambulatory system. The exchanges and filiations are now considered as complex, often in a two-way process: three of these cases were built in two separate campaigns at least (Limoges, Conques, ${ }^{43}$ and Tours ${ }^{44}$ ). Actually, the upper levels, which have disappeared at Tours and Limoges, raise the most crucial questions. But what distinguishes St Martial from its sister churches are its short and wide transept arms. That is precisely the consequence of the first campaign, when the monks wished to visualise either the reliquaries on the altar or the sarcophagus in its 'proper' place.

\section{Cult practices and the question of the reliquaries}

Can the architectural points be enlightened by what we know about the liturgy and the shrines? Sometimes, at pilgrimage sites, the remains of the saints had been forgotten. This was not the case in Limoges, where the relics as well as the sarcophagus were known without a break until the French Revolution, even if the grave had probably been cleared out and the saint dismembered to fill reliquaries. The sequence of this story is surprisingly well-recorded. Nevertheless, it remains a little bit contradictory; obviously, mystery was required to preserve the myth of the saint's presence in several sacred spots - and also to manage the discovery of relics! 
In 974 a golden seated statue of the saint was made, which was converted 20 years later into a reliquary, either for the head or for the entire body - it is not clear. ${ }^{45}$ It was as precious as the two famous contemporary golden altar frontals, one for the sepulchre, one for the abbey church. This transformation was contemporary with the building works, but the making of another container was probably necessary for the relics to travel, for example to honour the invention of the head of St John the Baptist at St Jean d'Angely. In 1028, during the dedicatio, it seems that the body was once more brought up, and ab initio sepultum jacet. $^{46}$

One century later, c. 1130, the head of Martial was ceremoniously recognised behind the altar, and was put inside a golden reliquary (the entire body was henceforth forgotten). ${ }^{47}$ But once more it is suggested that 'the saint was put again in his tomb'. Some trips were still organised with little bits of relic to help other monks: to Grandmont for example, so as to solemnise the church at its consecration on 4 September 1166. Most of the precious reliquaries and altar frontals disappeared in the plundering by the Young King in 1183, but the old urna aurea sancti Martialis, which was by then only used to collect alms, was still mentioned in 1207 when a sapphire was given. In 1211 the capsa was replaced by a new work, possibly made by the goldsmith Chatard who also promised to give a gold Eucharistic chalice. It is supposed that it was a large sarcophagus-shaped one (like the contemporary shrines from Agaune), because the silver plates with gilt reliefs of the Apostles were reused in the 17 th century. ${ }^{48}$ The relics were solemnly displayed to the faithful in the shrine, while the old one served to gather alms. It is interesting to note that the new reliquary was itself soon emptied; the Apostle's head was usually sheltered in another saint's reliquary.

Obviously the monks needed to reinvent their relics to imitate other pilgrimage sites and to give a greater fame to their Apostle. These ceremonial events are sometimes numbered under the title inventio by the chroniclers in an impenetrable chronological system: in a way they represent the first Ostensions which are still popular and held every seven years.

\section{ST MARTIAL'S ARCHITECTURAL SCHEME AS A MODEL IN THE DIOCESE?}

Beyond the multiplication of the funerary spots, another singularity must be pointed out: the St Martial type is isolated in the Romanesque landscape of the Limousin. For example, the pattern of the gallery level had absolutely no success in the area, nor the piers with four half columns, or, indeed, some other salient features.

\section{Ambulatories as an early trend in the Romanesque region}

Ambulatories are very numerous in the Limousin. In this context, it is impossible to prove that the St Martial

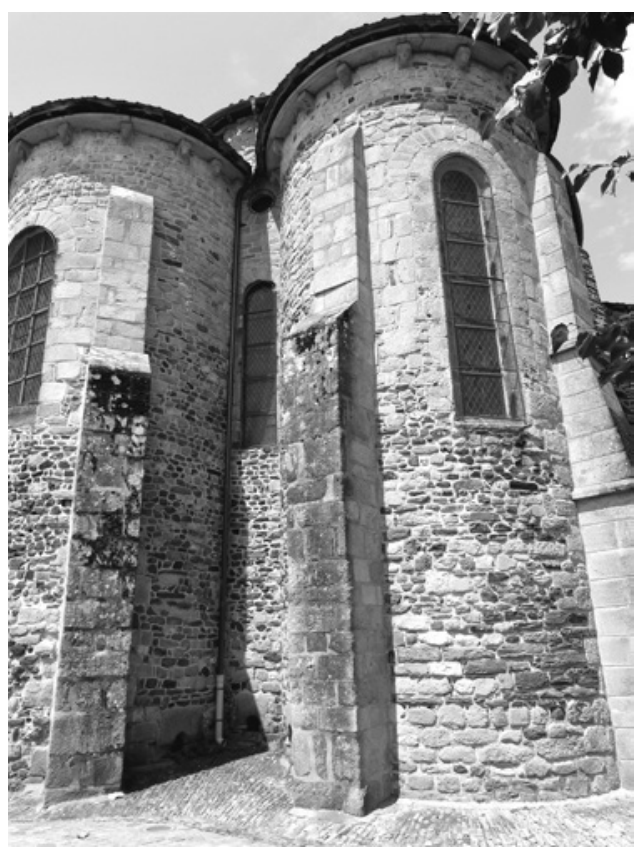

FIGURE 9.11

Uzerche: St Pierre, chevet (Claude Andrault-Schmitt)

design had an influence on the other cases. Toulx Ste Croix $^{49}$ and Chambon-sur-Voueize ${ }^{50}$ are daughters of St Martial: at Toulx the Apostle is said to have begun his preaching journey; at Chambon St Valeria's head was kept and venerated. However, two other ambulatories can be added to St Martial and Toulx from the early 11th century, which have neither religious nor formal connections with the church of the Saviour: the crypt ambulatory of the cathedral of Limoges (very difficult to grasp) and the double-level ambulatory at Uzerche ${ }^{51}$ (Figure 9.11), which is the best preserved and most interesting, but which is also a building which did not house any kind of saint's cult!

We must conclude that the ambulatory system was fashionable, and that at least five of them were built more or less contemporary to the well-known examples of Tournus, Auxerre, Chartres, Orléans, and Tours before the 1040s: in the cathedral, St Martial, Uzerche, Toulx, and Chambon. ${ }^{52}$ This background makes any accurate relative dating very difficult.

How, then, did monks and canons formulate architectural strategies to make a Limousin saint? Was St Martial a model for emulation during the 12th century?

\section{Le Dorat: an ambulatory to forge saints by suggesting pilgrimage}

As with St Pierre at Uzerche, Le Dorat housed no famous saints. The church was set in a little town with trade fairs and a college of secular canons which flourished near the castrum of the count de La Marche. To increase the attractiveness of their church, the canons decided to proclaim 


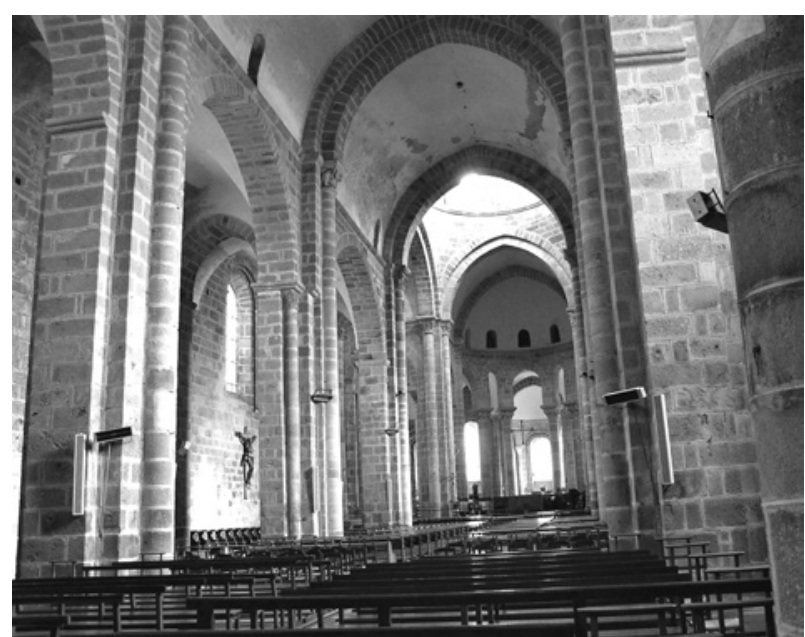

FIGURE 9.12

Le Dorat: St Pierre, nave and choir (Claude AndraultSchmitt)

that two earlier members of their community were saints: Israël $(\dagger 1014)$ and Théobald ( $†$ 1070), who are now the subjects of famous and very kitsch Ostensions. ${ }^{53}$ It is important to note that the two priests are not cited as saints before the 14th century. However, it is generally said that an elevation of relics took place in December 1130 after being prepared for by two short vitae that included miracles, but the liturgical sources in which we find celebrations of their cults date from 1614 and 1639; so we have to contemplate a single oral tradition. ${ }^{54}$ Given the weakness of the case for sanctity, it is likely that the architectural choices were at the heart of the matter.

It seemed necessary to build (c. 1130) two ambulatories, one around a large new crypt, the other in the church above it. ${ }^{55}$ The canons set in the crypt two stone reliquaries (less long than true sarcophagi), each of them raised on two piers and initially closed by iron bands - now the only evidence of the 12th-century strategy to create saints. Other features connect the building and the pilgrimage church type. For example, the piers with one semi-column only (towards the middle of the nave) are more similar to those at Toulouse than those at Limoges (Figure 9.12). Above all one can admire the high crossing tower, which is a lantern tower that can be identified from afar, thanks to its height and its golden angel.

\section{St Léonard-de-Noblat: a quotation of St Martial's Storeys?}

As mentioned, the author of the Liber Jacobi preferred a visit to St Léonard and overlooked Limoges. In St Léonard a 6th century hermit was buried, whose relics were supposed to free prisoners (like Ste Foy at Conques) and to aid pregnant women. The cult flourished from the beginning of the 11th century through several churches built on the same spot, among which the main and only durable one was initially dedicated to Trophime (perhaps a reference to a distant and more famous pilgrimage). ${ }^{56}$ Bohemond of Antioch and Richard the Lion Heart visited the church to thank the saint after their imprisonments, the first visit during Lent 1106 during a recruiting drive. ${ }^{57}$ The canons established there under the authority of the bishop were as conservative as the monks of St Martial: they did not want to demolish the older walls. ${ }^{58}$ The new parts of the buildings were added to the older parts or integrated into them in an accumulative way, so it is difficult to puzzle out the church (Figure 9.13).

The collegiate church has the remains of a woodenroofed structure including a transept and an aisleless nave built before the $1050 \mathrm{~s}$. These walls were preserved partly because of the numerous chains, irons, or fetters given as votive offerings, and partly because of a paradox: the site had no true and deep past, unlike St Martial. The stones were considered as proofs; the heterogeneity served to evoke the succession of several centuries. At the end of the 11th century but before the First Crusade, a rotunda was built against the northern arm to evoke the Holy Sepulchre. The eastern part of the nave was then embellished, stone vaulted, and connected with two domed arms and a lantern crossing (c. 1100). Afterwards a very high and famous gabled tower was added on the north side.

The 11th century chevet is unknown since the east arm was substantially enlarged $c .1130$ by an ambulatory, five radial chapels, and a clerestory. The ground plan seems somehow disproportionate and contorted, but the whole structure is carefully designed and would appear to have been very elegant before the 17 th century reinforcement.

The most interesting point is not the ambulatory, but the elevation, with a plain clerestory and low galleries (Figure 9.14). Those galleries are limited to the first bay of the new presbytery, exactly like those of the so-called Pilgrimage churches, where they do not continue around the apse. Perhaps these spaces served to lead the canons from their upper-level convent, but one cannot help thinking that these features (which thereafter became unfashionable) display an intentional resemblance to St Martial in the context of a publicity competition, Léonard emulating Martial.

\section{St Junien: an architectural reliquary to suggest the presence of a tomb-shrine}

Let me end with the case of St Junien, which proves that architectural strategies are always specific and sometimes unexpected, and which opens the discussion up to gothic types. ${ }^{59}$

We remain convinced that the major part of the monumental Romanesque church was built just before a dedicatio celebrated on 21 October 1100, although the use of pointed arches raises doubts among scholars. ${ }^{60}$ It has a beautiful crossing-lantern and very interesting capitals. That the first eastern arm was already abruptly squareended is well attested: a gable-end was described as paries orientalis ultimus. ${ }^{61}$ A hundred years later, the three aisles were lengthened in a conservative way (barrel and 


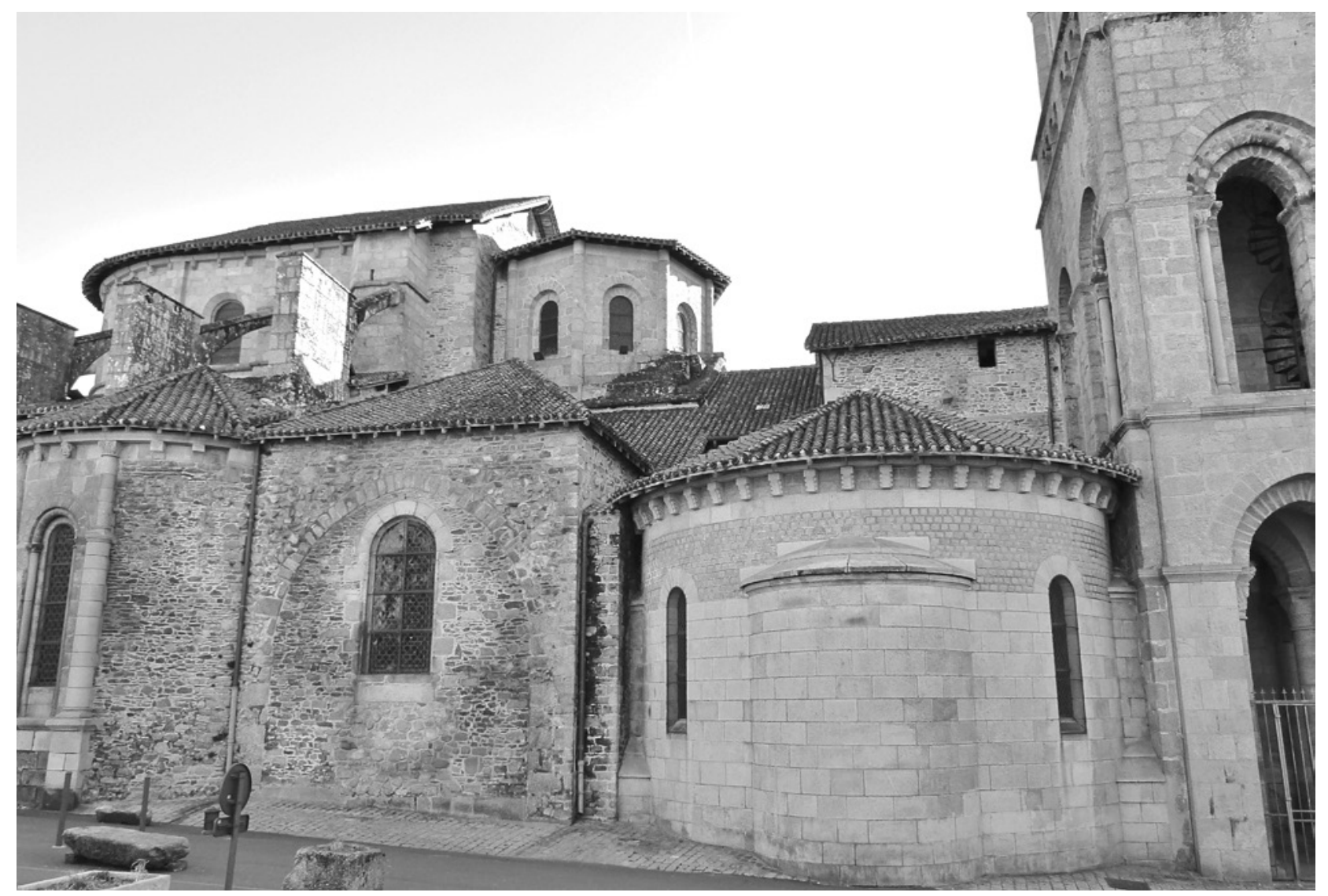

FIGURE 9.13

St Léonard-de-Noblat: North façade-the old transept between the rotunda and the 12th chevet (Claude Andrault-Schmitt)

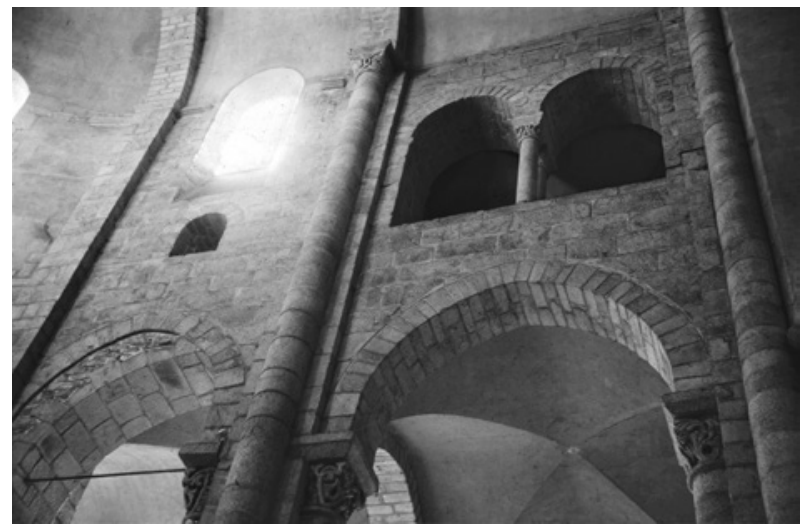

FiguRE 9.14

St Léonard-de-Noblat: First southern bay of the sanctuary (Claude Andrault-Schmitt)

groin vaulted), and a new gable end was built further east (Figure 9.15); ${ }^{62}$ the presbytery was changed into a sort of big box suitable to announce the presence of another box, the famous tomb-shrine, which encased the holy bones of the 6th-century founder and also the relics of his bishop, Rurice II, and those of his friend the hermit Amand.
The relative dating of the embellishments of the sanctuary and the transept due to the numerous and rich canons (and probably the bishop of Limoges) is difficult to establish within the three last decades of the 12th century, while the limestone carved sarcophagus dates from $c$. 1175-80. Parallel to the shrine, the nave was embellished to announce the saint's glory in the Heavenly Jerusalem to the common faithful: both by a tower built to heighten the first bay and by a splendid painted program on the eastern bay vault. The nave paintings echo the shrine's iconography, since they represent the Elders and the Paschal Lamb, not the saint's life on Earth.

Beyond the crossing, the tomb-shrine was partly built into the high altar $^{63}$ (and therefore for a long time hidden behind the canons choir), as was supposed to be the case in the 6th century in the church built by Rurice II for a community of priests. Following an inventio and elevatio in 990 (a date celebrated every year), ${ }^{64}$ connected with the making of a wooden painted reliquary, the reliquary, the shrine, and the altar were intimately associated. As at Santiago, ${ }^{65}$ the original aedicule (probably half buried) was removed, either in 990 or in 1100, but its walls, which were used in the new foundations, corresponded 


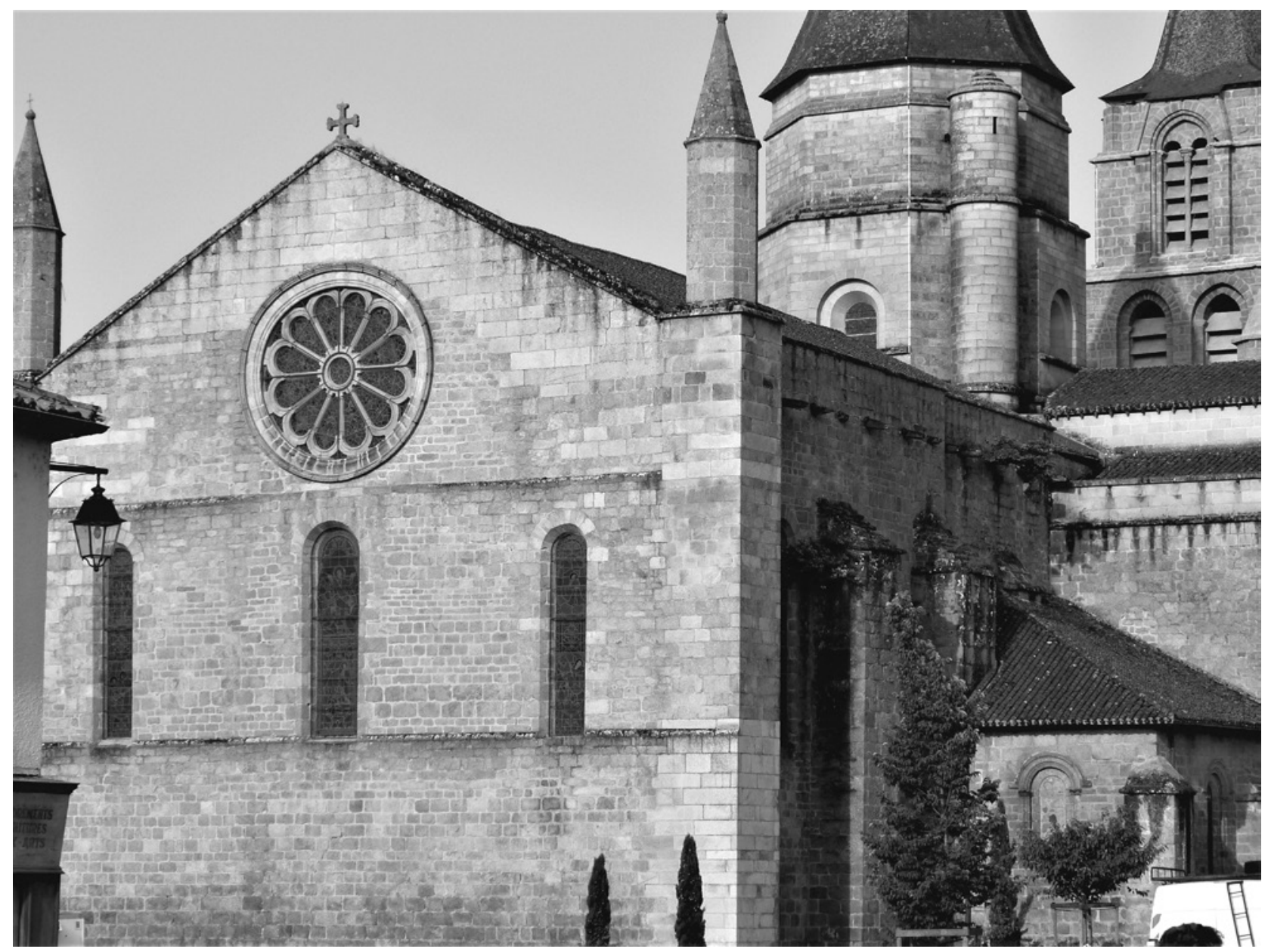

FIGURE 9.15

St Junien: East gable end, c. 1190 (Claude Andrault-Schmitt)

to the area of the canons choir. Above all, the site of the high altar always preserved the exact topographical point of the tomb.

It is worth noting that the setting of the famous carved shrine was turned into a sort of historical certification, based once more on a Russian doll system. For inside the shrine, through an oculus, one can see the internal sarcophagus of Junien. Behind it, a stone slab is carved with archaic letters (Figure 9.16). The technique of the letters suggests that the true 6th-century sarcophagus is housed in the carved shrine while the words suggest that the carved shrine was made for the dedicatio in 1100: that is, a sort of double forgery. The cover of the internal sarcophagus, a big stone ad modum dorsi asini fabricatum, ${ }^{66}$ is still used as a surface on which to place several small reliquaries: the shrine, apart from during Ostension periods, is now a kind of treasury.

Furthermore, at St Junien, thanks to the lengthening of the church, the liturgical subdivisions correspond to the architectural subdivisions. Thus, as at Rievaulx (Yorkshire): 'By amalgamating the monastic choir, high altar, tombs and shrine, the community reciprocally linked them' ${ }^{67}$ Contrary to Rievaulx, and as in Poitiers cathedral, the east front of St Junien cannot be considered as a cliff elevation or cliff-east-end strictly speaking because it is of a sort of hall type: the aisles are not lower or not much lower than the central vessel and consequently only one gable joins the three vessels together. ${ }^{68} \mathrm{~A}$ real cliff-east-end elevation is rare in France, but it does exist, as, for example, at Laon cathedral. During the Gothic period, we can evoke in Poitou the lengthening of the Cistercian church of Les Chatelliers, a daughter of Clairvaux, made to house a stone tomb-shrine for the founder Géraud de Sales, whose monks tried in vain to obtain his canonisation. ${ }^{69}$ There the lost shrine had six little columns, exactly the same number as the big columns of the new eastern part of the church. Perhaps the type of the recessed gable for the east wall of Les Chatelliers came from other Aquitanian experiences, such as the church of St Jean d'Angely, which displayed the head of St John the Baptist, but this abbey church is much too ruined to be discussed. 


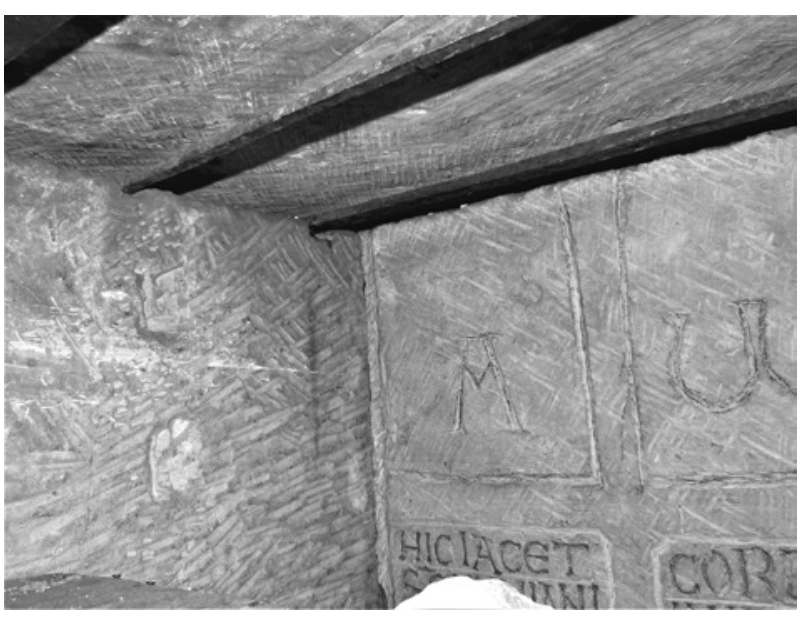

FigURE 9.16

St Junien: Inscription slab inside the carved shrine (Claude Andrault-Schmitt)

However relevant the term cliff-east-end for the buildings is, the cases of Saint-Junien at the end of the 12th century, Rievaulx a little later, and Les Châtelliers at the end of the 13th century, demonstrate that the architectural formula used to suggest the strong presence of a saint needed neither a crypt nor an ambulatory, thanks to the files of the piers which housed the sanctuary. Moreover, their sarcophagus-shaped architecture worked to announce their sarcophagus-shaped reliquaries.

\section{CONCLUSION}

Various strategies have been highlighted. For example, the Romanesque churches of St Martial and St Junien are roughly opposite in regard to the formal and liturgical features, even though they both represent a memorial for a 6th-century mausoleum.

After considering the monks' or canons' historicist strategies - a rich debate - we must point to a surprising common thread: the ways to lead pilgrims to the saints are rarely very practical - either behind an altar or beyond an uncomfortable staircase. ${ }^{70}$ What this demonstrates is that ambulatories did not represent utilitarian answers. Architecture is first and foremost image-making. The Limousin Ostensions, which are organised every seven years by 20 little towns and have been listed by UNESCO as Patrimoine culturel immateriel since 2013, revive medieval practice (Figure 9.17). On these days we can see that the crowd is not properly channelled by the building structure. We can also understand that the faithful are mostly attracted by gorgeous ceremonies on certain designated days. During the Middle Ages, contingent events such as a supposed inventio or elevatio were essential.

Whatever the scheme for the medieval pilgrimage churches, they all deserve the beautiful words concerning Tynemouth: Egrigii martiris protectio et venuste ecclesie pulcritudo, simile cunjuncte efficiunt quod fratres ibi

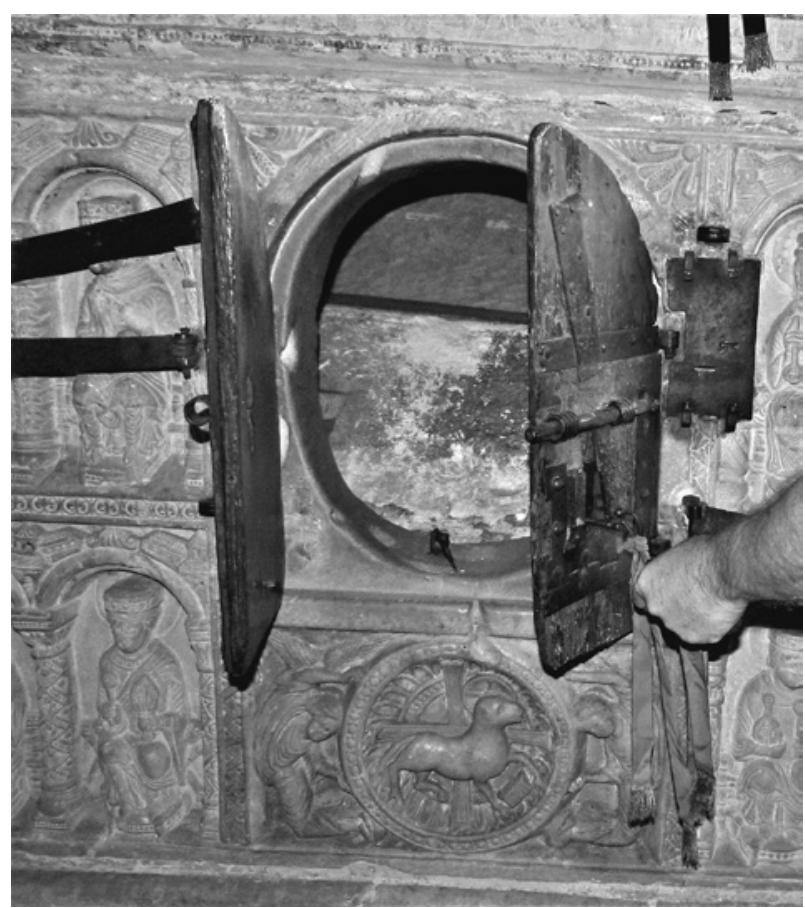

FigURE 9.17

St Junien: Opening of the shrine on the first morning of the Ostensions days: June 2016 (Claude Andrault-Schmitt)

habitantes simul ambulantes in domo domini cum consensu et ore et corde alacriter decantavant. ${ }^{71}$

\section{NOTES}

C. Andrault-Schmitt, ed., Saint-Martial de Limoges. Ambition politique et production culturelle ( $X^{e}$-XIII ${ }^{e}$ siècles) (Limoges 2006); E. Vergnolle, 'Limoges, Saint-Martial. L'abbatiale du Sauveur et les églises de pèlerinage', Haute-Vienne romane et gothique. L'âge d'or de son architecture, Congrès archéologique 2014 (Paris, 2016), 115140; 'L'archéologie médiévale au Siècle des lumières. Regards sur l'abbatiale du Sauveur à Saint-Martial de Limoges', in Les Arts réunis. Etudes offertes à Daniel Rabreau (Paris 2016), 181-188. We must now wait for the publication of the conference Saint-Martial de Limoges. Millénaire de l'abbatiale romane, 1018-1028 (Limoges, 29-30 novembre 2018), Bulletin Monumental.

2 Paris, BnF, ms. lat. 11907 fol 200.

3 Limoges, Arch. munic., DD 10, and Arch. dép., C 65, C 442.

4 X. Lhermite, 'Limoges. Crypte Saint-Martial', Bilan scientifique 2014. SRA (Limoges 2016), 74-75; 'Limoges. Abbaye Saint-Martial, église abbatiale du Sauveur: sondages 2014', Bulletin Monumental, 173 (2015), 65-67; 'Limoges. Place de la République', Bilan scientifique 2015. SRA (Limoges 2017), 87-90; 'Limoges. Abbaye Saint-Martial, église abbatiale du Sauveur: fouille programmée, campagne 2015', Bulletin Monumental, 174 (2016), 200-204; 'Limoges. Abbaye Saint-Martial, fouille programmée, campagne 2016', Bulletin Monumental, 175 (2017), 407-410. All these papers are abstracts from the voluminous annual final reports for the Service régional d'Archéologie (X. Lhermitte and A. Marty, Limoges, 2012 to 2017).

5 'Fouilles sur l'emplacement de l'abbaye de Saint-Martial. Rapport sur les travaux du 7 février 1960 au 14 juin 1960', Bulletin de la Société archéologique et historique du Limousin, 88 (1961), 49-71; 'Fouilles sur l'emplacement de l'abbaye de Saint-Martial, Place de la République à Limoges (suite)', Bull. Soc. Arch. Hist. Lim., 89 (1962), 29-53; M-M. Gauthier, 'Première campagne de fouilles dans le Sépulcre 
de Saint-Martial de Limoges', Cahiers archéologiques, 12 (1962), 205 248; J. Perrier, 'Fouilles sur l'emplacement de l'abbaye de Saint-Martial: église Saint-Pierre-du-Sépulcre, Limoges'(13 juin - 15 septembre 1966)', Bull. Soc. arch. hist. Lim., 94 (1967), 87-99; 'Fouilles sur 1'emplacement de l'abbaye de Saint-Martial, Limoges' (3 juillet - 4 septembre 1967)', Bull. Soc. Arch. Hist. Lim., 95, 1968 (117-130); R. Couraud, 'Découvertes archéologiques lors du creusement d'un parking souterrain Place de la République à Limoges (1968-1970)', Bull. Soc. Arch. Hist. Lim., 97 (1970), 45-79; J. Perrier, 'Recherches sur les sépultures médiévales en Haut-Limousin: la nécropole de Saint-Martial de Limoges', Travaux d'archéologie limousine, 1979-80, 101-111.

${ }_{6}$ The words are used to explain the earlier grant recorded for the church, in 1016: Limoges, Arch. départ., 3 H 89 (19). For the apostolic status, A. Dierkens, 'Martial, Sernin, Trophime et les autres: à propos des évangélisateurs et des apôtres en Gaule', in Saint-Martial (as n. 1), 25-37. In 1854, the apostolic status once again obtained the Roman approbatur!

'An Urbane Fraud', in Saint-Martial (as n. 1), 455-467.

Like Paul, 'who although he did not see the Lord in the flesh, will judge with Christ': R. Landes, Relics, Apocalypse, and the Deceits of History. Ademar of Chabannes, 989-1034 (Cambridge 1995), 314. This book, with wildly imaginative pictures and disputed historical interpretations, is controversial.

See particularly the Sermon for the dedicacio, Paris, BnF Ms. lat. 2469 , fol. $68 \mathrm{v}^{\circ}-70$, written by Ademar three years after the dedicatio itself and intended to provide proof for his apostolic status. The bibliography is unbounded: D. F. Callahan, 'The sermons of Ademar de Chabannes and the Cult of St Martial of Limoges', Revue bénédictine, 86 (1976), 251-295; P. Bourgain, 'La culture et les procédés littéraires dans les sermons d'Ademar de Chabannes', in Saint-Martial (as n. 1), 411-428. The sermons are edited in the recent thesis: B. Bon, 'Les sermons d'Adémar de Chabannes. Edition du manuscrit de Berlin', in Ecole nat. des chartes. Positions des thèses soutenues par les élèves (1999), 67-72; R. Richter, Martial et Adémar. Edition de 23 sermons du ms. autographe .. 2469; f. 1-76, ibid., 2003, 169-176; Z. Romaneix, Edition d'un manuscrit autographe d'Adémar de Chabannes, BnF lat. 2469, f. 76-112v, ibid., 2005, 189-196.

10 Commemoratio abbatum lemovicencium basilica S. Martialis Apostoli, H. Duplès-Agier ed. (Paris 1874), 7-10; Gallia Christiana, II, col. 558. See also: Basilica regalis Salvatoris incoata reedificari maiore amplitudine: Annales Lemovicenses, MGH II (Hanover 1829), col. 252. The word basilica came from Gregory of Tours and the epithet regalis is due to the Carolingian family. Neither the dating nor the abbot are clear, because we have several contradictory notices of the undertaking in Ademar's writings. Geoffrey, the viscount's brother and the bishop's uncle, who was said to have attended the ceremony, died in 1019 .

11 We now think that the context is not a competition between the cults, but indicates an accumulation principle. So also are the celebrations in the Cathedral and St Martial.

12 From an anonymous note in the margin of the Easter tables: $\mathrm{BnF}$ lat. 5239 fol 20 v.; MGH II, 252. See also 'Chronique de Vigeois', in Novae Bibliothecae manuscript librorum, ed. P. Labbe, II (Paris 1657), 283 (we await the imminent new edition and a translation of the Vigeois Chronicle).

${ }_{13}$ For literature on the shrine, see $\mathrm{n} .45$ below.

14 Secundo basilice ejusdem in ampliorem statum renovatae facta est anno incarnationis Christi millesimo XXVIII: Paris, BnF lat. 5257, after J-L. Lemaitre, Mourir à Saint-Martial. La commémoration des morts et les obituaires à Saint-Martial de Limoges $d u X I^{e}$ au XIII ${ }^{e}$ s. (Paris 1989), 236. This source was written $c .1063$, just contemporary with the Cluniac annexation.

${ }_{15}$ The new vita for Martial is called Vita prolixior but very badly edited (see Dierkens, 'Martial', as n. 6). Concerning the synods, which are historically obscure, Ademar tells us of his bloody debate against Benedict of Chiusa in 1029.

16 Before 1032: Bernard Itier: Chronique, J-L. Lemaitre, ed. and trans. (Paris 1998), 13; R. Gem, 'St Peter's basilica in Rome c. 1024 1059: A Model for Emulation?' in Romanesque and the Past, ed. J. McNeill and R. Plant (Leeds 2013), 49-66.

17 'Left in his habit': G. Pon, 'Compte Rendu', Cahiers de Civilisation médiévale, 44 (2001), 168. Ademar left Limoges to his convent
Saint-Cybard in Angoulême as early as 1029. See also Splendeurs de St-Martial de Limoges au temps d'Adémar de Chabannes (Musée de Limoges 1995), in which B. Barrière considers that 1029 put a stop to the campaign for apostolic status, not the contrary ('Adémar polémiste ou Martialis apostolus Christi', 65-77).

18 The coup d'Etat in 1063 is known from a factum: Paris, BnF, ms. lat., 11019, fol 165-168 (nota quomodo Cluniacenses occupaverunt locum Sancti Martialis) in L'abbaye de Saint-Martial de Limoges, ed. C. de Lasteyrie (Paris 1901), 427-429. It is also noticed by Geoffroy de Vigeois: Cluniacenses Monachi caput ordinis S. Benedicti invaserunt locum S. Martialis Lemovicensis (Labbe, Novae (as n. 12) 287). For the building sequence: C. Andrault-Schmitt, 'L'architecture de la grande église en questions', Saint-Martial (as n. 1), 219-239.

19 A. Sohn, Der Abbatiat Ademars von Saint-Martial de Limoges. Beiträge zur Geschichte des Alten Monetums und des Benediktinertums 37 (Münster in Westfallen 1989).

${ }^{20}$ Commemoratio (as n. 10).

21 Work on the Theatre Berlioz was in progress in 1837, contemporary to the first fragmentary archaeological observations and to the book by J.-B. Tripon, Historique monumental de l'ancienne province du Limousin (Limoges 1937).

${ }^{22}$ A fragment of another mausoleum has been recently detected to the north against a wall of the medieval chapter-house of St Martial. Several small churches which stem from mausolea have now been unearthed in the Limousin, sometimes in the heart of the countryside: St Hilaire at Moutier-Rozeille among others.

${ }^{23}$ X. Lhermite, 'Limoges. 1, rue de la Courtine', Bilan scientifique 2012, Service regional de l'archéologie (Limoges 2013), 102-104; Archéologie en Limousin, 1, rue de La Courtine (Limoges): du mausolée antique à l'église Sainte-Marie-de-la-Courtine (Limoges 2015).

${ }^{24}$ For the Virgin cult in 1220: B. Itier, Chronique (as n. 16), 60.

25 The word comes from a miracle that is supposed to have taken place $c$. 680: see J.-F. Boyer, 'Hypothèses au sujet de la basilique carolingienne du Sauveur du monastère Saint-Martial de Limoges', Bull. Soc. arch. hist. Limousin, 143 (2015), 63-88 which contains stimulating and disputed proposals.

26 1170-1172: D. Callahan, 'Eleanor of Aquitaine, the Coronation Rite of the Duke of Aquitaine and the Cult of Saint Martial of Limoges', in The World of Eleonor of Aquitaine. Literature and Society in Southern France Between the Eleventh and Thirteenth Centuries, ed. M. Bull and C. Léglu (Woodbridge 2005), 29-36.

${ }^{27}$ P. Depreux, 'Le testament de saint Yrieix', in Les chapitres séculiers et leur culture. Vie canoniale, art et musique à Saint-Yrieix (VIe-XIII ${ }^{e}$ siècle), ed. C. Andrault-Schmitt and P. Depreux (Limoges 2014), here 172-173 ('we give this bread gift to those who serve saint Martial').

28 There are many archaeological levels at the east, and the excavations in 2015 revealed the former southern wall. The first discussion by X. Lhermite, 'Abbaye Saint-Martial de Limoges. Recherches en cours sur l'église Saint-Pierre-du-Sépulcre', Bull. Soc. Arch. Hist. Limousin, 140 (2012), 1-19.

${ }_{29}$ Itier, Chronique (as n. 16), 9; Gallia Christiana, col. 557.

30 See $\mathrm{n}$. 5. The mosaic has sometimes been dated between the 6th and the 9th century. A copy is now displayed in the 'archaeological crypt'; the real one is preserved in the museum. As for the inscription (also in the museum), it was found in 1780 . The publications of the 1960s papers have become less and less relevant, not only because of the brevity of the archaeological works, but also because of their historical interpretations.

31 Itier, Chronique (as n. 16), 43. Contrary to what is generally said, this is not second-rate decoration but an expensive one: such gilt tinrelief stars survive in Poitiers Cathedral from c. 1290.

${ }^{32}$ Bourgain, 'La culture' (as n. 9).

33 Ephémérides de la Généralité de Limoges pour l'année 1765 (Limoges 1765). For the iron doors in 1211, Itier, Chronique (as n. 16), 39. For the words 'crypta' or 'hypogea', J. Crook, The Architectural Setting of the Cult of Saints in the Early Christian West. c. 300-1200 (Oxford 2000), 49-50.

${ }^{34}$ Legros, in Feuille hebdomadaire de la généralité de Limoges, 27 mai 1778; 18 mai 1785. Or L. Guibert, Archives historiques du Limou$\sin$ (1902), 364-369. The tombs of his fellows which were set close to that of Martial had been brought up to the basilica or at least emptied 
to give relics to other churches. One of them (Austreclinien) was put behind the high altar where his cult would develop in the 12th century.

35 See Gauthier, 'Première campagne'; G. Lintz, 'Les sépultures de 1'Antiquité tardive sur le site de Saint-Martial (fouilles de 1972-1974)', in Saint-Martial (as n. 1), 137-152. For another grave which contained beautiful bishop's ring: E. Dabrowska, 'La tombe de l'évêque A . . . et la sépulture ecclésiastique à Limoges', Bulletin de la Société nationale des Antiquaires de France (2000), 248-264. The legend of the duke named 'Tèves le Duc' (the Duke Etienne?) is a very complicated matter.

36 In his fundamental book (as n. 33), Crook noticed that 'There was little room for circulation, but the saint miraculously created more space by moving his tomb-fellows to one side' (51). Later the use of candles in the Sepulchre would substitute for the burying ad sanctos: as, for example in 1215 for the knight-poet Bertran de Born (Itier, Chronique (as n. 16), 48)

37 This form of sarcophagus-shaped reliquary is discussed by A. Dierkens, who also develops the notion of the bipolarity for many cults: 'Du bon et du mauvais usage des reliquaires au Moyen Age', in Les reliques. Objets, cultes, symboles, ed. E. Bozoky and A-M. Helvetius (Turnhout 2000), 239-252. This paper evokes the case of Fosses (EntreSambre-et-Meuse) in which one can read the same process as in St Martial (the integration of a former mausoleum in an underground annexe). See also Crook, The Architectural (as n. 33).

38 Boyer, as n. 24. See also L. Bourgeois and J-F. Boyer, 'Les palais carolingiens d'Aquitaine: genèse, implantation et destin', in Demeurer, défendre, paraître: orientations récentes de l'archéologie des fortifications et des résidences aristocratiques médiévales entre Loire et Pyrénées (Chauvigny 2014), 67-118.

39 Y. Chauvin and G. Pon, Adémar de Chabannes. Chronique (Turnhout 2003), 211.

40 Sermon for the Celebration of the 10th October: the recent thesis edition of the Sermons is not easily accessible, but they are used by Bourgain in 'La culture' (as n. 9). A French translation is in M.-M. Gauthier, 'Sermon d'Adémar de Chabannes pour la translation de saint Martial le 10 octobre', Bull. Soc. Arch. Hist. Limousin, 88 (1961), 72-82.

${ }^{41}$ But the area of the 'Guardian Angels chapel' mentioned in the ancient drawings and descriptions, and which was used for a long while as a vestibule to lead to the Low Church, contains very old and unexpected remains.

42 Regarding the comparison made by the author of the Liber Sancti Jacobi between Tours and Santiago, we must refer to the translation from B. Gicquel, La légende de Compostelle. Le livre de Saint-Jacques (Paris 2003) which is in my opinion the best one in French. It helps us to understand that the comparison concerns the process and the ambition, not the architectural type: 'Here, as at Santiago, a great and remarkable basilica was built above his tomb and for his honour' (616).

43 É. Vergnolle, H. Pradalier and N. Pousthomis-Dalle, 'L'abbatiale de Conques, les campagnes romanes', in Monuments de l'Aveyron, Congrès archéologique de France 2009 (Paris 2010), 71-160.

44 P. Martin, 'Les premiers chevets à déambulatoire et chapelles rayonnantes de la Loire moyenne' (PhD thesis, Poitiers, 2010). See also 'Saint-Martin de Tours. Nouvelles propositions pour la datation du chevet du $\mathrm{XI}^{\mathrm{e}}$ siècle', in Livraisons d'histoire de l'architecture et des arts qui s'y rattachent, 25 (2013), 83-96; 'Les transepts à collatéraux et tribunes des grandes églises ligériennes de l'an mil', in Le transept et ses espaces élevés dans les églises du Moyen Age central. Pour une nouvelle approche fonctionnelle, Lausanne Conference 2015 (in press). See also Richard Gem's contribution in this volume.

45 The chroniclers are contradictory. See J-F. Boyer, 'Reliquaires et orfèvreries à Saint-Martial', Saint-Martial (as n. 1), 39-57; 'Catalogue des reliquaires et objets d'orfèvrerie à Saint-Martial de Limoges', Bull. Soc. arch. hist. Limousin, 134 (2006), 101-162. 994 is the date of the 'miracle des Ardents' which needed a little trip to a suburb for the relics.

${ }^{46}$ Geoffroy de Vigeois, Chronicle, 17-18: Tunc quoque levatum est corpus ... Et post octo dies totum relatum est et reservatum est integrum corpus ejusdem antistis in sepulcrum pristinum ab initio sepultum jacet.

47 Geoffroy de Vigeois, 301. Itier, Chronique (as n. 16), 19.
48 Boyer, 'Catalogue' (as n. 45), 117. Most of the purchases of the period are listed in Itier, Chronique (as n. 16), 35-64, because the armarius was also a treasurer who ordered the payments, but Itier did not describe a sarcophagus-shaped shrine.

49 P. Martin, 'L'église Saint-Martial à Toulx-Sainte-Croix', in SaintMartial (as in n. 1), 281-293.

${ }^{50}$ C. Andrault-Schmitt, 'Archaism or Singularity? The Nave Clerestory in Romanesque Architecture Between the Loire and Dordogne', Romanesque (as n. 16), 95-108.

51 L. Boulesteix, 'Lecture archéologique de la crypte romane', Haute-Vienne (as n. 1), 31-41; The Limousine Crypts, thesis in process, Poitiers. To all these cases must be added at least four 12th-century ambulatories in the diocese: Lesterps, Bénévent, Beaulieu-sur-Dordogne, and Saint-Robert.

52 An early campaign for the Chambon chevet has been recently suggested by Eric Sparhubert.

53 This case is quoted by Crook, The Architectural (as n. 33), 272.

54 A. Massoni and E. Sparhubert (eds) Israel du Dorat. Etre chanoine en l'an Mil (Limoges 2019) especially the papers from P. Bouchaud, H. Caillaud and E. Sparhubert.

55 Sparhubert, 'Le Dorat. Collégiale Saint-Pierre', in Haute-Vienne (as n. 1), 245-268.

56 E. Sparhubert, 'Saint-Léonard-de-Noblat, collégiale Saint-Léonard', in Haute-Vienne (as n. 1), 219-244.

57 For Bohemond, see the story from Grégoire de Bechade in L. Patterson, 'Occitan literature and the Holy Land', The World of Eleonor (as n. 25), 84. At that time, c. 1100, a reform of the canons was probably established (not in 1062-1063).

58 'A holy site was efficacious because it was permanent and unchanging': R. Ousterhout, 'Architecture as Relic and the Construction of Sanctity. The Stones of the Holy Sepulchre', Journal of the Society of Architectural Historians, 62 (2003), 3-23. The next words are more appropriate to St Martial than to St Léonard: 'it provided a direct link between the ritual of veneration and the historical event it commemorated'.

59 I have examined architectural creation at stake in the strategies of the promotion of the sanctity in 'Edifier: les enjeux de la création architecturale dans les stratégies de promotion de la saintete $\left(\mathrm{XI}^{\mathrm{e}}-\mathrm{XIII}{ }^{\mathrm{e}}\right.$ siècle)', in Hagiographie, idéologie et politique au Moyen Age en Occident, ed. E. Bozoky (Turnhout 2012), 315-346. Some of my favourite cases were raised some years ago by Crook, The Architectural (as n. 33)

60 E. Sparhubert, 'Les commandes artistiques des chapitres de chanoines séculiers et leurs enjeux: édifier et célébrer à Saint-Junien $\left(\mathrm{XI}^{\mathrm{e}}\right.$ XIII ${ }^{\mathrm{e}}$ siècles)' (PhD thesis, University of Poitiers, 2009); 'Saint-Junien, collégiale Saint-Junien', in Haute-Vienne (as n. 1), 269-296. 277.

${ }_{61}$ Maleu Chronicle, quoted by Sparhubert, 'Saint-Junien' (as n. 60),

62 A miracle seems to date the new gable to a time after 1230 . However, the true dating is some years before 1223, because that is the date given by Maleu for a lean-to chapel east of the north arm. Built against both the first bays of the chevet and the new bays of the chevet, this chapel is consequently posterior to the lengthening; and its dating (1223) corresponds very well with its features.

${ }^{63}$ Reminding us the words of St Ambrose during the translation of Sts Gervais and Protais (c. 385): 'Christ super altare, the saints sub altari' (Crook, The Architectural (as n. 33), 13).

${ }_{64}$ Maleu Chronicle, after Sparhubert, 'Saint-Junien' (as n. 60), 274.

65 E. Carrero Santamaria, 'Le sanctuaire de la cathédrale de SaintJacques-de-Compostelle à l'épreuve de la liturgie', in Saint-Martial (as n. 1), 295-307.

${ }^{66}$ Maleu Chronicle, after Sparhubert, 'Saint-Junien' (as n. 60), 143.

67 P. Fergusson and S. Harrison, Rievaulx Abbey. Community, Architecture, Memory, with contributions from G. Coppack (New Haven and London 1999), 174.

${ }^{68}$ The first east front of St Junien, in the eleventh century, had perhaps more recesses, but it is uncertain: Sparhubert 'St Junien' (as n. 60), 275 . 
69 1247-1277. See several of my papers. Recently: 'L'expression architecturale chez les claravalliens de l'Aquitaine du nord: les abbatiales des Châtelliers, Boschaud et Valence (1129-1277)', in Le temps long de Clairvaux. Nouvelles recherches, nouvelles perspectives (XII ${ }^{e}-X X I^{e}$ siècle), dir. A. Baudin and A. Grélois (Département de l'Aube 2016), 261-282.

70 A good example is the abbey Church of St Denis before Suger. One of the most typical cases is the great church of Santiago itself, where the original aedicule was suppressed, unlike Limoges (Carrero
Santamaria, 'sanctuaire' (as n. 62)). See also B. Brenk, 'Les églises de pèlerinage et le concept de prétention', in Art, Ceremonial et Liturgie au Moyen Age, ed. N. Bock, P. Kurmann, S. Romano and J-M. Spieser (Rome 2002), 125-139.

71 C. 1190, Cambridge, University Library, Ms Ec.4.20 (15th century copy), after H. H. E. Craster, A History of Northumberland, VIII (Newcastle-upon-Tyne-London 1907), 71-73. I owe many thanks to David Rollason for the reference. 